DOI: $10.17805 / z p u .2015 .3 .18$

\title{
К изучению индивидуального тезауруса Николая Станкевича
}

\author{
А. Н. СвАЛОВ \\ (РОССИЙСКАЯ АКАДЕМИЯ СОЦИАЛЬНЫХ НАУК, Г. МОСКВА)
}

В настоящей статье рассматриваются особенности формирования и содержания тезауруса Николая Станкевича - русского философствующего мыслителя и просветителя 1830-х годов. Автор отмечает, что гуманитарно-познавательная активность выступала важнейшей составляющей жизненной стратегии Станкевича. Эта активность была органично увязана с установкой на самоорганизацию и саморазвитие его личности. С позиций тезаурусного подхода даются обобщенные оценки кружка Станкевича, в котором проявлялся запрос на новое европейское знание, новые смыслы, выражаемые философией, искусством, литературой, исторической наукой.

Автор, развивая положения тезаурусной теории, полагает, что тезаурус в качестве субъектно освоенного знания активно способствует внутренней ориентации самого субъекта, пониманию им своей субъектности; без такой внутренней ориентации трудно говорить об ориентации субъекта в окружающей среде.

В статье показаны компоненты разных видов и форм знаниевого комплекса Станкевича - «человека мысли и сердца».

На примере ранней философской работы Станкевича «Моя метафизика» характеризуются исходные, наиболее значимые идеи и положения, которые определяют особенности ядра тезауруса Станкевича. По мнению Станкевича, обогащение внутренней, духовной жизни человека выступает первейшей предпосылкой для совершенствования общественной жизни, для поступательного развития России.

Ключевые слова: тезаурусный подход, индивидуальный тезаурус, Н. В. Станкевич, кружок Станкевича, русская философия XIX в., просвещение.

\section{ВВЕАЕНИЕ}

$\mathrm{O}$ бщегуманитарная тезаурусная теория и тезаурусный методологический подход позволяют более внимательно подойти к пониманию особенностей личности и творчества известных деятелей науки и культуры, их индивидуальных жизненных практик.

Формирование, накопление, выстраивание тезауруса (не забудем, что он не более чем актуальный научный конструкт, отражающий особенности функционирования знаниевой системы) представляет собой, как известно, многофакторный процесс 1 . На тезаурус субъекта - нас в данном случае интересует индивид - несомненно влияют особенности исторического времени, положение самого субъекта в макро- и микросоциальном пространстве, сказываются различные социальные факторы. Однако значимое субъектно организованное знание не может быть порождено, накоплено, освоено, по необходимости отрегулировано без усилий самого человека как социального субъекта, тем более если речь идет об индивидуальном (персональном) тезаурусе. Человек с его индивидуальными особенностями, в том числе физиологическими и психическими, во многом взращивает - непосредственно и опосредовано, осознанно и неосознанно - свой неповторимый тезаурус, является его носителем, взаимодействует с тезаурусами других людей, тех или иных малых групп и иных социальных общностей.

Отмеченное в полной мере подтверждается при обращении к неординарной фигуре философствующего мыслителя, идеалиста-гуманитария с широкими интересами Николая Владимировича Станкевича. 


\section{УСТРЕМАЕННОСТЬ К ЗНАНИЯМ}

Станкевич - выходец из потомственных дворян, имевших по мужской линии иноземные корниㄹ. Воспитывался он, по характеристике А. И. Герцена, стройно и широко, «на всей барской воле». Отец Николая, Владимир Иванович (1786-1851), был крупным помещиком-предпринимателем в Воронежской губернии, авторитетным в дворянском сообществе, так что его статус предусматривал жизнь активную, деятельную. В сонном царстве Николай, его братья и сестры уж точно не росли.

Аетство Станкевича - это детство ухоженного дворянского ребенка - ясное, достаточно спокойное. Родители отличались «честным отношением с детьми»; их власть чувствовалась в доме «не как гнет, а только как ограничение воли, еще необузданной размышлением, и почти всегда как ограничение разумное и снисходительное» (Анненков, 1857: 13-14). Семья не только способствовала начальному накоплению знаний (преимущественно в форме восприятия и освоения ориентирующей информации «в готовом виде», важной для жизненного становления и социализации в период детства), но и создавала благоприятный фон для последующих размышлений Станкевича о своих жизненных траекториях, о необходимости жить гармонично, в согласии с собой и другими людьми.

Важнейшее значение для развития тезауруса имеет образование. Аля родителей Станкевича, а семья была многодетной, было характерно повышенное внимание к обучению и воспитанию детей, развитию их умственного и общекультурного кругозора.

Николай Станкевич вначале, в 1822-1824 гг., обучался в Острогожском уездном училище Воронежской губернии. В октябре 1825 г. его отдали в частный благородный пансион в Воронеже, образование в котором - в основном по гимназической программе - он завершил в июне 1830 г. (Свалов, 2015а). Это были важные годы для определения познавательных приоритетов и накопления знаний. Во-первых, к старшим классам проявилось явное предпочтение гуманитарной области познания - словесности, истории, причем значительное время Станкевич начинает уделять необязательным занятиям, самообразованию. Во-вторых, интерес к гуманитарному знанию подкреплялся первыми проявлениями художественного творчества. Николай пишет стихи, некоторые из которых с 1829 г. публиковались в московских и петербургских журналах. Весной 1830 г. в Москве была издана написанная им трагедия в стихах «Василий Шуйский». Понятно, что это не могло не влиять на тезаурус как субъектно накапливаемое знание, на начальное понимание автором своей социокультурной субъектности.

Внешние обстоятельства благоприятствуют Николаю. Немаловажным фактором выступал материальный достаток семьи. А. И. Герцен, отмечая особенности его воспитания, писал: «Аовольство дает развязную волю и ширь всякому развитию и всякому росту, не стягивает молодой ум преждевременной заботой, боязнью перед будущим, наконец оставляет полную волю заниматься теми предметами, к которым влечет» (Герцен, 1975: 122). В семье он находил понимание и поддержку, и әто при том, что традиции серьезного интеллектуально-духовного наследства отсутствовали. Станкевича жестко не стреножили, считались с его интересами, не объявляли познавательные и творческие устремления пустыми, некой блажью, как это нередко бывало в других семьях. За него заранее не определяли пути выхода в жизнь, не побуждали непременно служить ради карьеры или быть «при хозяйстве». Не будем удивляться, что осознанное желание Станкевича поступить в Императорский Московский университет было одобрено семьей. 
Учеба на словесном отделении университета в 1830-1834 гг. подтвердила, что для Станкевича характерна познавательная активность, что для него существенно именно гуманитарное знание. На собственном примере он убедился в пользе университетского образования, о чем заявлял неоднократно. «У нас невозможно дать себе стройного образования, - напоминает он ближайшему другу Я. М. Неверову, 一 тем больше удалившись от университета, каков бы он ни был. Университетская жизнь много значит» (Переписка ..., 1914: 341).

Московский университет того времени переживал переходную полосу, «архаический период» в его истории уходил в прошлое. Аа, еще оставались профессора, читавшие лекции по старинке, которым трудно было ориентироваться в новых тенденциях развития наук, интеллектуальной и духовной жизни. Но наблюдалось и оживление преподавания, при Станкевиче на словесное отделение пришли хорошо подготовленные, с новыми мыслями и подходами ученые - Н. И. Надеждин, С. П. Шевырев, М. П. Погодин. Содержательными и полезными были и занятия у давно служивших профессоров, к их числу относились М. Т. Каченовский, М. Г. Павлов. Станкевичу было чему и у кого учиться.

Очевидно, что молодой Станкевич проявлял повышенный интерес не просто к знаниям, а к знаниям современным. Чужие мысли, смелые суждения и обобщения были весьма полезны для развития собственных. Аекции, беседы с профессорами, особенно теми, кто выступал для Станкевича как значимые другие, зачастую служили стимулом и отправной точкой для его серьезной самостоятельной работы, «выучивания себя». Станкевич прекрасно осознавал, что за свой уровень знаний, внутренний рост в ответе не профессора, даже лучшие из них, а прежде всего он сам. Организованное университетское учение и самоучение для него были неразрывны. Объем дополнительной работы был очень весомым, она занимала времени не меньше, чем занятия непосредственно в университете. И вот мы видим Николая, покупающего нужные книги в лавках, заказывающего научные издания из Петербурга, постоянно читающего, выполняющего переводы с иностранных языков, посещающего интересных людей дома, обсуждающего с друзьями понятные и непонятные темы.

\section{КРУЖОК СТАНКЕВИЧА: К НОВОМУ ЗНАНИЮ}

Отдельно следует сказать о московском литературно-философском кружке, вошедшем в историю как кружок Станкевича. Он начал спонтанно формироваться на исходе 1831 г. из потребности углубления знаний, «для совокупных трудов на поприще образованности», но в этом отношении был не столько продолжением, сколько дополнением университета. Эта малая группа, будучи проявлением социальной самоорганизации, стала сборным местом для своих, близких по мыслям и чувствам юношей, в то время приверженцев главным образом романтизма как многоликого феномена в развитии культуры. В «Былом и думах» Герцен отмечал: «...Между нашим кругом и кругом Станкевича не было большой симпатии. Им не нравилось наше почти исключительно политическое направление, нам не нравилось их почти исключительно умозрительное. Они нас считали фрондерами и французами, мы их - сентименталистами и немцами» (Герцен, 1975: 99). В свете тезаурусного подхода налицо отделение «своего» от «чужого». В самом деле, интересы кружка Станкевича, как ранее любомудров 1820-х годов, сосредоточивались на философии, особенно новейшей немецкой, на литературе, искусстве. Несмотря на стремление к свободной мысли, от вопросов социальных и политических уклонялись, они находились «за спиной», высту- 
пали «чужими» ${ }^{3}$. Поэзия жизни в окраске романтического идеализма интересовала неизмеримо больше, чем проза жизни с ее противоречиями и проблемами. Однако недостаточно констатировать оппозицию. Как нередко бывает, отнесение определенных познавательных интересов к «чужим», в данном случае характерным для кружка Герцена-Огарева, помогало социальной ориентации, поддержанию интереса к ценностному «своему», отвечающим ему актуальным смыслам.

При всей пользе умственных занятий в университете (учтем, что он находился под постоянным присмотром властей) именно кружок сыграл важнейшую роль в определении и формировании знаниевого «своего»- коллективного (группового) и индивидуальных тезаурусов. Не в ходе университетской учебы, а в пространстве кружка в наибольшей мере проявлялся интеллектуально-творческий запрос на новое европейское знание, новые смыслы, выражаемые философией, искусством, литературой, исторической наукой (Жукова, 2014: 107). Эти «внешние» знаниевые фрагменты, смыслы участники кружковой «братии» воспринимали не пассивно - в обстановке многоголосного взаимодействия, когнитивного сопряжения они стремились их продумать (иногда и прочувствовать), актуализировать и интериоризировать прежде всего в целях определения возможностей и путей возвышения человека, обогащения его внутренней, духовной жизни. Тем самым те или иные аспекты переработанного европейского знания способствовали формированию у кружковцев уже собственно своего знаниевого контекста, который воспринимался каждым индивидуально, в том числе в зависимости от опыта, личностных особенностей и интересов. Молодые люди были убеждены, что Humanität (нем.) - человечность может быть присуща только тому, кто определился со своими высокими взглядами на жизнь, с убеждениями, кто готов следовать им в практической, поведенческой деятельности.

Кружок создавал свою среду бытования: разговоры, споры за чаепитием на серьезные и волнительные темы нередко заканчивались весельем, в ходу были шутки, розыгрыши и даже дружеские насмешки, на которые, как правило, не обижались.

Аля Станкевича это небольшое гуманитарное сообщество (устава и членства в нем не было) - ближайшее социальное окружение, в котором он выступал «огромной субстанцией». «Он имел сильное значение в своем кругу, - отмечал Константин Аксаков, - но это значение было вполне свободно и законно, и отношение друзей к Станкевичу, невольно признававших его превосходство, было проникнуто свободною любовью, без всякого чувства зависимости» (Аксаков, 1989: 189). Такая неформальная роль побуждала нашего героя быть «на уровне», показывать пример отношения к осваиваемым знаниям, к духовному, нравственному развитию личности. Об этом свидетельствуют, например, его философское сочинение «Моя метафизика» (1833) и философическая повесть «Несколько мгновений из жизни графа Z***» (1834), а также письма, читать которые и в наше время полезно и интересно.

Свое место, свою роль по активному воздействию на сознание, на знаниевые составляющие других кружковцев Станкевич, несмотря на прирожденную мягкость, прекрасно понимал. В этой связи ограничимся обобщениями выдающегося философа и социолога А. А. Зиновьева: «Человек должен чувствовать, что он занимает определенное место в сознании других людей, причем место, с его точки зрения, адекватное его собственным представлениям о себе. Он должен ощущать, что он не является излишним, что другие не являются полностью индифферентными к нему. И он сам должен ощущать потребность в других людях» (Зиновьев, 2006: 346). Сказанное в полной мере применимо к Станкевичу. 
Кружок не только жил в эпоху «возбужденности умственных интересов» (Герцен), но и вносил своей деятельностью весомый вклад в формирование этой эпохи. Как известно, он продолжал собираться и после окончания Станкевичем и его сотоварищами университета; состав изменялся, пополнялся новыми лицами, но по-прежнему сохранялось выбранное им направление, по-прежнему для его участников была велика востребованность общения, познания, творческих начал.

\section{ПОЗНАВАТЕАЬНАЯ АКТИВНОСТЬ И ЖИЗНЕННЫЙ МИР}

Узнавание и познание неотделимы от жизни Станкевича. Это важнейшие составляющие его индивидуального жизненного мира ${ }^{4}$, которыми он всегда дорожил. «Признаюсь тебе, друг мой, - пишет он в декабре 1835 г. Я. М. Неверову, - ход человеческого ума, его стройное развитие и приращение, вечная истина, облекающаяся в разные одежды, соответственно веку и народу, и все более и более являющая свою сущность, — какое явление может быть занимательнее?» (Переписка ..., 1914: 341).

Обратимся вновь к некоторым страницам личной истории Станкевича. После окончания в июле 1834 г. университета со степенью кандидата он испытывал определенные затруднения в выборе вариантов для дальнейшей деятельности. Его не привлекает учительская и тем более канцелярская служба. Не склонен он и непосредственно помогать вести хозяйство в имении, заниматься помещичьим предпринимательством по примеру отца. Но вот вариант найден: занять место почетного смотрителя в Острогожском училище, том самом, в котором он проходил свое первое учение. В августе 1835 г. министр народного просвещения утверждает Станкевича в этой должности. Однако почти сразу Станкевич готов «охотно подать в отставку» (там же: 329 )5. Почему? Аа, выяснилось, что необходимо поправить здоровье, пройти курс лечения в Москве. Но главная причина иная: Станкевича тянет к родным стенам и интересам, привычной для него жизни, а потому в Москве ему «отраднее, нежели где-нибудь» (там же: 324). Он предпочитает общаться в кругу значимых для него людей, заниматься «на свободе» изучением философии, гуманитарных наук, брать уроки музыки, посещать театр и читать книги, полезные и волнующие душу, мечтать о любви. В этом он видит свою «блаженную жизнь»; он остерегается жить обыденно, «как все», без интеллектуального и духовно-душевного напряжения.

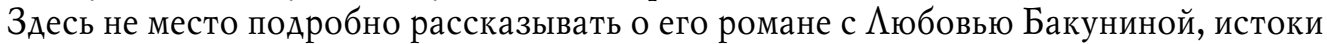
которого относятся к началу 1835 г. Напомним только, что почти одновременно с получением в середине марта 1837 г. ответа отца о готовности благословить женитьбу Николай Станкевич решает покинуть Россию, ссылаясь на необходимость лечения за границей. Сердечная история оказалась свернутой, а фактически завершенной, хотя открыто об этом он не заявил, понимая, каким сильным ударом это было бы для Бакуниной, преданно любившей его, но так и не ставшей невестой. Станкевич склонен ссылаться на сомнения в истинности своих чувств, эти чувства, мол, искажались, преувеличивались, в то время как душа была «бедна». Однако главная причина завершения романа с юбовью Бакуниной, как мы понимаем, не столько в недостатке чувств со стороны Николая, сколько в его неготовности к браку, к событию, ведущему к событию. Когда дорога к брачному союзу открылась, он побоялся сделать решительный шаг, который неизбежно привел бы к новой ситуации, переменам в стиле, повседневном укладе собственной жизни. Потенциально брак мог бы внести и существенные, в том числе нежелательные, изменения в жизненную стратегию с ее ценностными ориентациями и действиями. Отсюда новая сильная волна рефлексии и саморефлек- 
сии, порождавшая, в частности, признания в своей «неспособности к любви». Отсюда решение о скорейшем отъезде за рубеж, выглядевшее, несмотря на все разъяснения, как бегство от Бакуниной. Показательно, что Станкевич (оставим в стороне фактор болезни туберкулезом) не жалел о последовавших заграничных годах, ибо они были наполнены содержанием его привычного мира - прохождением новой «школы знаний» в Берлинском университете, частными уроками у лучших профессоров, обстоятельным изучением философии Гегеля, других видных представителей философской и әстетической мысли, знакомством с историческими и культурными памятниками в разных европейских странах.

Аля Станкевича постоянная гуманитарно-познавательная активность - неотъемлемое, более того, наиболее значимое проявление жизненной стратегии. Причем эта активность осознанная, смысловая, действенная, она непосредственно увязана с субъективно свободным выбором своего «Я», с установкой на самоорганизацию и саморазвитие. Несомненно, что эта установка сложилась под значительным влиянием романтизма с его акцентом на самоценность человека, суверенной личности.

Станкевич из немногочисленного числа тех, кто «бескорыстно ищет истины» и тем самым «уже очищает душу и приготовляет ее к принятию божества» (Переписка ... , 1914: 366). При этом он чужд узкоутилитарного подхода к знаниям (ради карьеры, гражданской службы, помещичьего благополучия). Он убежден, что серьезное овладение знаниями, особенно новейшими, выступает главным условием саморазвития человека, его интеллектуального и духовного обогащения. Тем самым процесс познания, развертывающийся на протяжении жизни, способствует соединению человека с «полным Разумением».

В контексте ранее сказанного отметим, что в рамках тезаурусной теории необходимы, по нашему мнению, определенные дополнения, когда речь идет о главном назначении знаниевого тезауруса - ориентации социального субъекта в окружающей среде. Мы имеем в виду, что субъектно освоенное и организованное знание с присущей ему иерархичностью направлено прежде всего на внутреннюю ориентачию самого субъекта, понимание им своей субъектности, что позволяет определять и выстраивать важнейшие параметры жизненного мира, в данном случае индивида 6 . Без такого назначения тезауруса трудно говорить об ориентации субъекта в окружающей среде.

\section{ЗНАНИЕВЫЕ КОМПОНЕНТЫ}

Очевидно, что в тезаурусе Станкевича представлены компоненты разных видов и форм знания.

В одном из писем 1833 г., т. е. еще в период университетской учебы, Станкевич заявит: «Может быть, науки со временем совершенно заменят мне жизнь; начало этому я уже вижу» (Переписка ..., 1914: 252). Станкевич всегда был открыт научному знанию. Он умел - иногда это требовало немалых усилий, например при изучении системы трансцендентального идеализма Ф. Шеллинга или, скажем, априорных категорий И. Канта, - понимать новизну и критически оценивать те или иные научные построения и выводы. Однако наука, несмотря на приведенное выше заявление, не заменила ему жизнь, а научное знание при всей важности составляло лишь один из компонентов его знаниевого комплекса. Кроме науки для него весьма существенно знание, накапливаемое в других формах общественного сознания (видах деятельности всеобщего духа, если следовать Гегелю) - искусстве, религии, философии. 
Станкевич неоднократно отмечал важность познавательной функции искусства. Он, как и другие романтики-идеалисты (здесь велико влияние немецкого романтизма), разделял положения о значимости искусства, в котором наблюдается единение сознательного и бессознательного, для познания истины. Ведь искусство всегда живет, развивается в неразрывной связи с божественным Аухом (Абсолютом). В повести «Несколько мгновений из жизни графа Z $* * *$ » он называет искусства «представителями неба на земле» (Станкевич, 2008: 146). Очень интересны более поздние суждения Станкевича в незаконченной статье «Об отношении философии к искусству» (1840). В ней он, среди прочего, пишет не только об «элементе» общего, вечного, - божественного в искусстве, но и о том, что в искусстве проявляется «элемент» «цельной, индивидуальной жизни, нераздробленного знания», выражающий вечную «потребность человека в каждое мгновенье сознавать всю нераздробленную полноту своей жизни » (там же: 159$)^{7}$. Аля обретения такого «нераздробленного знания» недостаточно умозрительных усилий - искусство как раз и способствует образному восприятию и пониманию мира, воспитывает ум чувствующий и переживающий. В то же время автор, исходя из положений Гегеля, относящихся к эстетике, истории искусства, подчеркивал значение понятийных определений, рационального знания, что шло, в частности, вразрез с творческой «чистой интуицией», которой увлекались некоторые любомудры. Аля Станкевича важна как мысль, так и поэзия искусства. «Станкевич как мыслитель, - справедливо обобщает современный философ и культуролог И. Н. Сиземская, - никогда не был исключительно философом, занимающимся отвлеченными умозрительными построениями, как не был только почитателем искусства, пренебрегающим философской рефлексией» (Сиземская, 2013: 1434).

Не случайно, конечно, его рефлектирующая мысль зачастую неотделима от образов, впечатлений, переживаний, возникающих во время просмотра театральных постановок, посещения концертов музыки, при чтении художественных произведений. К лучшим из них Станкевич относил те, которые помогают «внутреннему ощущению» всеобщего духа, в поэтической форме которых проявляется философская интенция. За «художнически-рефлективное» направление Станкевич высоко ценил Ф. Шиллеpa, И. В. Гете, Э. Гофмана, - в их художественных произведениях пространство для мысли и возвышенных чувств.

Обнаружить и воспринять новые знаниевые составляющие, обогатить себя новыми образами, впечатлениями, переживаниями он активно старался и во время проживания за границей, знакомясь с памятниками искусства разных стран.

Применительно к религиозному компоненту напомним известное высказывание Станкевича из письма к В. Г. Белинскому от 30 октября 1834 г.: «Между бесконечностью и человеком, как он ни умен, всегда остается бездна, и одна вера, одна религия в состоянии перешагнуть ее, одна она в состоянии наполнить пустоту, вечно остающуюся в человеческом знании» (Переписка ... , 1914: 408). Станкевич убежден, что без религии «нет человека», без нее не постичь саму суть и полноту жизни. Отмечая взаимодополнение различных знаниевых компонентов, он заявлял, что «упрочить религию может одна философия» (там же: 338), ибо она, в частности, показывает возможности и пределы человеческого разума, которому не все подвластно. Однако и религия с ее ощущением таинства жизни должна не опровергать или принижать, а подтверждать могущество человеческого ума, который тоже имеет божественное порождение. Небезынтересен в этой связи пассаж из письма 1836 г.: «Аа и чем передается тебе религия? не умом ли! Разве верование не есть мысль, мысль, одобряе- 
мая целым разумением, которое невольно и безотчетно сознает свое единство с нею?» (там же: 365$)$.

Компонент актуального философского знания, немецкого прежде всего, занимает вообще особое место в тезаурусе Станкевича. Мы не будем приводить достаточно известные сведения о его серьезном изучении трудов Шеллинга, Канта, Гегеля, внимании на исходе своей жизни к $\Lambda$. Фейербаху. Подчеркнем только, что уже с университетской поры его интересовала возможность создания стройного знания, которое позволяет философу «из одной главной идеи строить мир идей, отдельную, свою вселенную» (там же: 237). Правда, одно время у него наблюдался некоторый скептицизм в этом отношении, что нашло отражение в его критических замечаниях о философии Шеллинга и Канта, но к концу 1835 - началу 1836 г. скептицизм в основном был преодолен. Показательны строки в письме к М. А. Бакунину от 24 ноября 1835 г.: «Я не думаю, что философия окончательно может решить все наши важнейшие вопросы, но она приближает к их решению; она зиждет огромное здание, она показывает человеку цель жизни и путь к этой цели, расширяет ум его. Я хочу знать, до какой степени человек развил свое разумение, потом, узнав это, хочу указать людям их достоинства и назначение, хочу призвать их к добру, хочу все другие науки одушевить одною мыслию» (там же: 594). Более отчетливо о цельном знании он говорит в сентябре 1836 г. в письме к Т. Н. Грановскому, находившемуся в зарубежной командировке: «...Я хочу полного единства в мире моего знания, хочу дать себе отчет в каждом явлении, хочу видеть связь его с жизнью целого мира, его необходимость, его роль в развитии одной идеи» (там же: 450). Убежденность в достижение такого знания значительно окрепла у него после обращения к философии Гегеля.

Станкевич, конечно, признавал значимость прагматичного знания, но критично относился к односторонности, встречавшимся крайностям. «Я не понимаю, - высказался он однажды, - натуралиста, который считает ноги у козявок, и историка, который начав с Ромула, в целую жизнь не дойдет до Наумы Помпилия...» (там же: 446). Подобных натуралистов и историков - «бедных голов» - Станкевич осуждает за то, что они, будучи апологетами частного, «бегут от мыслителей», от «коренных вопросов знания», ответы на которые дает новейшая европейская философия. Отсюда и вывод: больше знать не означает лучше, отчетливее знать (там же: 450).

\section{В ФОКУСЕ КАРТИНЫ МИРА - ЧЕАОВЕК}

Нам теперь необходимо остановиться на содержательных рядах тезауруса Станкевича, которые связаны с пониманием особенностей и назначения человека, возможностей совершенствования человеческой жизни. А это определяет гуманитарное знание «высокого порядка», которое находит выражение, как полагают Вал. А. $\Lambda$ ков и Вл. А. Ауков, в сверхориентационной функции тезауруса (Ауков В., Ауков Вл., 2013: 32-34). Аействительно, такое знание, опирающееся на соответствующие ценностные ориентации, возвышается над знаниями, направленными на жизнеобеспечение (мы бы добавили: и на поддержание повседневной жизнедеятельности) в окружающей среде; оно досоздает эту среду, наполняет новыми смыслами, новым содержанием жизнь человека. Именно такое знание характерно для ядра тезауруса ${ }^{8}$ Станкевича. Причем он вполне осознанно понимает и провозглашает значимость сверхориентации не только для себя, но и для других людей из образованного общества.

Каковыми могут быть параметры сверхориентационного знания и убеждений, формированию которых оно способствует, убедительно показывает уже первая, неболь- 
шая по объему философская работа Станкевича «Моя метафизика», выполненная в форме двух писем к Неверову, отосланных в марте 1833 г. (третье письмо, вероятно начатое, не сохранилось) $)^{9}$. Авторское название сочинения было, однако, другим «Моя религия ${ }^{10}$, и такое название объяснимо, ибо Станкевич в нем определяет сredo «символ веры», которым собирается руководствоваться в жизни: «... это моя религия, одна, кажется, какую я могу иметь (при теперешних моих понятиях, по крайней мере)» (ОПИ ГИМ. Ф. 372. Оп.1. А. 4. А. 5 об. $)^{11}$.

B credo нашло выражение знаниевое «свое», накапливавшееся в университетских стенах, в ходе кружковых дискуссий, в результате чтения научных исследований, собственных размышлений. Это разнообразное «свое» привело автора к эклектизму, при наиболее заметном влиянии шеллингианства 12 . Вместе с тем әклектизм не помешал ему создать оригинальный трактат. И в нем - новое авторское «свое», которое достигнуто в том числе за счет отбора и интерпретации ранее освоенных знаниевых фрагментов.

В «Моей метафизике» можно увидеть, какие исходные и наиболее значимые идеи и положения находятся в ядре тезауруса Станкевича. Так, для него очевидно, что человек - неотъемлемая часть общей жизни природы. «Bce (das All) есть жизнь, а жизнь действует разумно, следовательно, сопряжена с Разумением» (Станкевич, 2008: 154). По непреложным законам Творца (Разумения) развивается в своем единстве вся жизнь, и «роды существ составляют лестницу, по которой жизнь (разумеющая себя в целом) идет к самоуразумению в неделимых» (там же). Последняя ступень такой лестницы представлена человеком, который принципиально отличается от других «неделимых». Только в человеке жизнь сознает себя вся, разумною и свободною, вследствие чего человек «может возвышаться над видимым; он может восходить к Разумению, отождестворяться (s'indentifier) с ним, он может проникнуть [в] его законы, провидеть его цели, чувствовать красоту создания; он может верить, надеяться, любить» (там же). Только человек («в чистом смысле слова, сохранивший все то, что составляет человечество») есть образ Творца (Разумения) (там же).

Следовательно, человек должен знать и понимать свое особое место на лестнице природы, жить сообразно своей особости. Увы, человек пал, но пессимистического уныния мы не увидим в этой философской работе. Выход из падения имеется: он в «приближении к всеобщей жизни», которой - кто станет отрицать? - свойственно «и разумение, и свобода действия, и чувство». И далее Станкевич поясняет применительно уже к человеческой жизни: «Как жизнь она имеет стремление (по сродству, может быть) усвоить вне ее лежащее, познавать, и как жизнь - развить себя во внешности, дейстъовать. Как жизнь она сознает влияние другой жизни, чувствует» (там же: 155-156). Таким образом, человек выступает у Станкевича разумеющим, волящим и чувствующим, и в единстве этих трех сторон он должен проявлять себя в реальной жизни.

При этом наш автор отдельно говорит о любви. Она предстает всеобщей, мировой жизнеутверждающей силой - благодаря энергии любви жизнь непрерывно творит и развивает себя. Но не утверждение любви как субстанционально-метафизического явления главное для Станкевича. Феномен «всеобщей любви» интересовал его прежде всего для обоснования значимости любви человеческой. Аля Станкевича несомненно, что любовь позволяет «восходить к Разумению», выражая тем самым имманентное стремление человека (далеко не всегда осознаваемое) обрести свою полноту и завершенность. В то же время Станкевич в нравственно-гносеологических аспектах 
рассматриваемой нами темы отмечает важность любви для повседневной жизни человека: «...человек только тогда все познает, когда любит, и кто любит, тот действует прекрасно» (там же: 156).

В «Моей метафизике» - мы не случайно остановились на этом сочинении - отчетливо проявляется потенциал тезауруса с его ценностно-целевой сверхориентацией. Субъектно организованное знание Станкевича оказывается предпосылкой для актов понимания, для сознательно-волевых действий, поступков. Современный читатель увидит, что это сочинение не демонстрация Станкевичем своего знания как такового, им двигало желание поделиться пониманием особенностей человека, его высоким назначением, стремление призвать людей к должной жизни, достойной человека. Отсюда и его убеждение, к которому он будет возвращаться неоднократно: «взаимные отношения людей должны очистить, образовать совершенного человека...». «Отсюда, - пишет он, - несомненная, хотя и не новая истина: жизнь рода человеческого есть его воспитание» (там же: 157). В дополнение приведем еще и строки из письма Станкевича к Неверову от 19 сентября 1834 г.: «...Постепенное воспитание человечества есть одно из сладчайших моих верований. И как отрадно видеть его в согласии с бытием природы, с сущностью человеческого знания, человеческой воли!» (Переписка ..., 1914: 290-291).

\section{ЗАКАЮЧЕНИЕ}

Мы вряд ли ошибемся, если скажем, что не единожды у интересующей нас персоналии в воображении возникал образ совершенного, или, как он иногда метафорично говорил, нормального, т. е равного «самому себе» человека - обогащенного знаниями, восприимчивого к чувствам своим и других людей, открытого любви и дружбе, умеющего понимать и ценить искусства, в силу внутренних, духовных побуждений религиозно верующего. Человека с творческим посылом, отчасти неудовлетворенного собой. Человека, практическая деятельность которого, принося пользу другим, обществу, сообразуется с его ценностными жизненными ориентирами.

\section{ПРИМЕЧАНИЯ}

1 При подготовке настоящей работы использованы положения тезаурусной теории и тезаурусного подхода, изложенные в книгах Вал. А. и Вл. А. Ауковых (Иуков Вал., Ауков Вл., 2008, 2013).

${ }^{2}$ Аед Николая Станкевича - Иван Семенович был сербом из города-крепости Задар (Зара) в Аалмации, входившей до 1797 г. в состав Венецианской республики. В 1757 г. в поисках лучшей жизни он приехал в Россию и принял «вечное подданство». Кстати, сербской фамилии Станкевич как таковой не существует. Это измененный русский вариант фамилии, которая в Аалмации была иной: скорее всего Ста́нкович (см. подробнее: Свалов, 2015b: Электронный ресурс).

3 Аля некоторых членов кружка, как известно, «чужие» интересы в дальнейшем окажутся «своими», М. А. Бакунин тому наиболее яркий пример.

4 Здесь для нас важно определение жизненного мира как метафорической формы субъективного видения индивидом своей жизни.

5 Отец его был против отставки. На указанной должности, не проявляя особого усердия, Николай оставался до июня 1837 г.

6 «Как прекрасно отказаться от счастья толпы, создать себе свой мир и стремиться к нему, хотя не достигая», - пишет в октябре 1833 г. Станкевич (выделено курсивом нами. - $A$. C.) (Переписка ..., $1914: 252$ ). 
7 Текст несколько отличается от рукописи, сохранившейся в архиве Станкевичей (см.: Отдел письменных источников Государственного Исторического музея - ОПИ ГИМ. Ф. 351. Оп. 1. A. 6.. .51$)$.

8 В обобщающей работе В. и Вл. Ауковых под ядром тезауруса субъекта понимается картина мира, «включающая, образно-понятийное представление о мире и человеке и подобное реальной картине: это именно картина (в четырехмерном облике, включающая координату времени)» (Иуков, В., Ауков, Вл., 2013: 253, 228-232). По нашему мнению, тезаурусное ядро может составлять не картина мира в целом, если она социальным субъектом до конца не определена, а какая-то ее значимая часть. Объясняется это тем, что не каждый субъект может иметь картину мира в указанном понимании, как и не каждый человек может иметь более или менее определенное мировоззрение.

9 Обратим внимание: Станкевич писал немного и, как правило, для себя и ограниченного круга читателей - значимых для него, способных разделить его мысли и чувства (к публичной авторской известности он не стремился). Писать ему важно и для себя, поскольку мысль изреченная, письменно высказанная помогает осознанию своего, а при необходимости и стимулирует дальнейшую познавательную активность. Примером тому и «Моя метафизика».

10 (См. подробнее: Велижев, 2008). Название «Моя религия» не было пропущено цензурой в 1849 г. Трактат под измененным названием впервые был опубликован в 1857 г. (Анненков, 1857: 17-24).

11 Это высказывание Станкевича опубликовал Ю. В. Манн в своей монографии «Русская философская эстетика (1820-1830-е гг.)» (Манн, 1969: 200). Очевидно, что в этом высказывании «вера» не тождественна религиозной вере, а слово «религия» используется для усиленного выражения убеждений, в которые «верует» Станкевич.

12 Самих трудов Шеллинга к тому времени Станкевич еще не читал. Интересно заметить, что кроме узнавания об идеях этого немецкого философа в университете и при чтении философской литературы важнейшим источником для восприятия шеллингианства выступала поэзия Шиллера.

\section{СПИСОК АИТЕРАТУРЫ}

Аксаков, К. С. (1989) Воспоминание студентства. 1832-1835 // Московский университет в воспоминаниях современников (1755-1917)/ сост. Ю. Н. Емельянов. М. : Современник. 735 с. C. 312-335.

Анненков, П. В. (1857) Николай Владимирович Станкевич. Переписка его и биография. М. : Типография Каткова и $\mathrm{K}^{\circ} .395$ с.

Велижев, М. В. (2008) «Моя метафизика»: к истории текста // Русская литература. № 2. C. $102-105$.

Герцен, А. И. (1975) Собр. соч. : в 8 т. М. : Правда. Т. 5.384 с.

Жукова, О. А. (2014) К интеллектуальной истории русского европеизма // Философские науки. № 1. С. 103-115.

Зиновьев, А. А. (2006) Глобальный человейник. М. : Алгоритм ; Эксмо. 448 с.

Ауков, В. А., Ауков, Вл. А. (2008) Тезаурусы: Субъектная организация гуманитарного знания. М. : Нац. ин-т бизнеса. 784 с.

Ауков, В. А., Ауков, Вл. А. (2013) Тезаурусы II: Тезаурусный подход в понимании человека и его мира. М. : Нац. ин-т бизнеса. 640 с.

Манн, Ю. В. (1969) Русская философская эстетика (1820-1830-е гг.). М. : Искусство. 304 с.

Переписка Николая Владимировича Станкевича, 1830-1840 (1914)/ редакция и изд. Алексея Станкевича. М. : Изд. Станкевича. 787 с.

Свалов, А. Н. (2015а) Воронежские годы Николая Станкевича // Знание. Понимание. Умение. № 1. С. 197-205.

Свалов, А. Н. (2015b) Из родословной Николая Станкевича [Электронный ресурс] // Информационный гуманитарный портал «Знание. Понимание. Умение». № 2 (март - апрель). 
C. 110-128. URL: http://zpu-journal.ru/e-zpu/2015/2/Svalov_Genealogical-Tree-Stankevich/ (дата обращения: 12.06.2015).

Сиземская, И. Н. (2013) Н. В. Станкевич и отечественная общественная мысль первой трети XIX века // Философия и культура. № 10 (70). С. 1428-1435.

Станкевич, Н. В. (2008) Избранное / вступ. ст. и прим. Б. Т. Удодова. Воронеж : Центр духовного возрождения Черноземного края. 304 с.

Аата поступления: 06.07.2015.

\section{STUDYING THE INDIVIDUAL THESAURUS OF NIKOLAI STANKEVICH}

\section{A.N. SVALOV \\ (RUSSIAN ACADEMY OF SOCIAL SCIENCES, MOSCOW)}

The article examines the development and contents of the individual thesaurus of Nikolai Stankevich, Russian thinker who flourished in the 1830s. Studies in the humanities formed the most important element of the philosopher's strategy of living, which was in organic unity with his general drive towards self-organization and self-development. From the standpoint of thesaurus approach, we provide a generalized assessment of the 'Stankevich circle' with its orientation towards new European knowledge and the achievements of its philosophy, art, literature and historical studies.

Building on the notions of the thesaurus theory, we suggest that the thesaurus as knowledge mastered by a subject, actively promotes self-orientation of such subject. Without this orientation, it is hard to speak of any self-positioning in the external environment.

The article outlines various kinds of components of Stankevich's knowledge complex as a 'man of thought and heart'.

Stankevich's early philosophical piece "My metaphysics" is analyzed as a collection of his original and most important ideas and provisions which form the core the author's thesaurus. He believed enriching man's inner, spiritual life to be the prime prerequisite for perfecting social life and for progressive development of Russia.

Keywords: thesaurus approach, individual thesaurus, N.V. Stankevich, Stankevich circle, $19^{\text {th }}$ century Russian philosophy, Enlightenment.

\section{REFERENCES}

Aksakov, K. S. (1989) Vospominanie studentstva. 1832-1835 [A memory of studenthood, 1832-1835]. In: Moskovskii universitet v vospominaniiakb sovremennikov (1755-1917) [Moscow University in the memoirs of its contemporaries (1755-1917). Moscow, Sovremennik Publ. 735 p. Pp. 312-335. (In Russ.).

Annenkov, P. V. (1857) Nikolai Vladimirovich Stankevich. Perepiska ego i biografiia [Nikolai Vladimirovich Stankevich: His letters and biography]. Moscow, Katkov \& C .395 p. (In Russ.).

Velizhev, M. V. (2008) «Moia metafizika»: k istorii teksta [My metaphysics: On the history of the text]. Russkaia literatura, no. 2, pp. 102-105. (In Russ.).

Herzen, A. I. (1975) Sobranie sochinenii [Collected works]: in 8 vols. Moscow, Pravda. Vol. 5. 384 p. (In Russ.).

Zhukova, O. A. (2014) K intellektual'noi istorii russkogo evropeizma [On the intellectual history of Russian Europeanism]. Filosofskie nauki, no. 1, pp. 103-115. (In Russ.).

Zinov'ev, A. A. (2006) Global'nyi cheloveinik [The global manhill] Moscow, Algoritm ; Eksmo. 448 p. (In Russ.).

Lukov, V. A. and Lukov, Vl. A. (2008) Tezaurusy: Sub' ektnaia organizatsiia gumanitarnogo znaniia [Thesauri: The subject organization of knowledge in the humanities]. Moscow, National Institute of Business. 784 p. (In Russ.).

Lukov, V. A. and Lukov, Vl. A. (2013) Tezaurusy II: Tezaurusnyi podkbod v ponimanii cheloveka $i$ ego mira [Thesauri II: Thesaurus approach to the conceptualization of the person and his/her world]. Moscow, National Institute of Business. 640 p. (In Russ.). 
Mann, Iu. V. (1969) Russkaia filosofskaia estetika (1820-1830-e gg. ). [Russian philosophical aesthetics (1820s-1830s)]. Moscow, Iskusstvo Publ. 304 p. (In Russ.).

Perepiska Nikolaia Vladimirovicha Stankevicha, 1830-1840 (1914) [The correspondence of Nikolai Vladimirovich Stankevich] / ed. by Aleksei Stankevich. Moscow, A. Stankevich. 787 p. (In Russ.).

Svalov, A. N. (2015a) Voronezhskie gody Nikolaia Stankevicha [Nikolai Stankevich: the Voronezh years]. Znanie. Ponimanie. Umenie, no. 1, pp. 197-205. (In Russ.).

Svalov, A. N. (2015b) Iz rodoslovnoi Nikolaia Stankevicha [From the genealogical tree of Nikolai Stankevich]. Informatsionnyi gumanitarnyi portal "Znanie. Ponimanie. Umenie», no. 2 (MarchApril) [on-line] Available at: http://zpu-journal.ru/e-zpu/2015/2/Svalov_Genealogical-TreeStankevich/ (accesses: 12.06.2015). (In Russ.).

Sizemskaia, I. N. (2013) N. V. Stankevich i otechestvennaia obshchestvennaia mysl' pervoi treti XIX veka [N.V. Stankevich and the Russian social thought of the first third of the $19^{\text {th }}$ century]. Filosofiia i kul'tura, no. 10 (70), pp. 1428-1435. (In Russ.).

Stankevich, N. V. (2008) Izbrannoe [Selected works] / Intr. and comm.. by B. T. Udodov. Voronezh, Tsentr dukhovnogo vozrozhdeniia Chernozemnogo kraia. 304 p. (In Russ.).

Submission date: 06.07.2015.

Свалов Александр Николаевич - кандидат исторических наук, академик Российской академии социальных наук, г. Москва. Тел.: +7 (495) 399-15-83. Эл. адрес: ava-69@mail.ru

Svalov Aleksandr Nikolayevich, Candidate of History, Full Member, Russian Academy of Social Sciences, Moscow. Tel.: +7 (495) 399-15-83. E-mail: ava-69@mail.ru 